RESEARCH ARTICLE

\title{
Student activism and democratic quality in Ghana's Fourth Republic
}

Ransford Edward Van Gyampo*

\section{Abstract}

Student activism has been pivotal in Ghana's political and democratic history. Prior to Ghana's Fourth Republic, student activism was highly confrontational and entailed student support or opposition to the various regimes depending on the extent to which the regimes were accepted by all as being rightful or legitimate. After 23 years of uninterrupted constitutional democracy, Ghana has earned the accolade of being a successful electoral democracy. However, in terms of democratic progression, the mere conduct of periodic elections that sometimes lead to alternation of power is described as elementary and a low quality democracy. Given that Ghana's democratisation process since 1992 has not been static, some remarkable strides have been made in improving the nation's democratic quality. Using a purely qualitative research design and interviews with some former student activists, this study argues that the modest strides made in the quest for high quality liberal democracy in Ghana cannot be meaningfully discussed without acknowledging the invaluable contributions of student activism. The study further suggests a relationship between democratic quality and student activism. It postulates that the shift from the usually oppositional and sometimes violent student activism in Ghana's Fourth Republic could partially be attributed to the country's strides made in the drive towards democratic maturity. For students to continue their role as vanguards of democracy in Ghana, the study recommends an amalgamation of all tertiary networks and other student splinter groups under the National Union of Ghana Students; and a shift in the modus operandi of the Union from confrontation to the use of dialogue and other peaceful democratic means to achieve its objectives. This could contribute to the restoration of the Union's former glory as a united, national and independent mouth-piece of students in all national issues.

\section{Keywords}

students, activism, protests, demonstration, democratic quality.

* Senior Lecturer, Department of Political Science, University of Ghana. Email: vangyampo@yahoo.com 


\section{Introduction and problem statement}

Students in Ghana, particularly those at the tertiary level, have played a critical role in Ghana's democratisation process. From Ghana's struggle for independence to the nation's current Fourth Republic's democratic dispensation, student activism has served as the fulcrum around which political action has revolved. This explains why, after the inception of the nation's Fourth Republic, the main political parties in Ghana established student wings on the campuses of the various tertiary institutions. For instance, the National Democratic Congress (NDC) has established the Tertiary Institution Network (TEIN) while the New Patriotic Party has established the Tertiary Education and Students' Confederacy (TESCON). The Convention Peoples' Party has also established the Tertiary Students' Charter (TESCHART). These student wings are expected to offer support and "win more souls" for the parties on the various campuses. The relevance of student activism is also seen in the run up to elections in Ghana. Since 1992, all political parties and political aspirants have thronged to the campuses of the various tertiary institutions to explain their programmes, ideologies, philosophies and manifestoes to students and to whip up their support during national elections (Asante, 2012, p. 222).

The question that ought to be posed however is whether the relevance of student activism must only be confined to its role of getting leaders elected and removing them from power. Indeed, the work of scholars like Oquaye (1980), Nugent (1996), Ninsin (1996), Chazan (1983), Shillington (1992), Tetteh (1999), Awoonor (1990), Kimble (1963), Austin (1964), Lentz (1995), Gyimah-Boadi (1993), and even recently, Nunyonameh (2012) depicts and unfortunately confines the role of student activism in democratisation to the arena of offering support through demonstrations, petitions and elections to regimes and agitating for their removal using the same channels when leaders of the regimes had either violated or failed to protect the fiduciary trust reposed in them. In terms of democratic quality, this role of student activism can only produce low quality democracy (Diamond \& Morlino, 2005, p. 49). However, this paper posits that student activism has contributed immensely towards Ghana's journey to attaining a high quality democratic status. How has this happened in Ghana's Fourth Republic? This is the area that seems not to have been fully and extensively researched. Using a purely qualitative and historical approach, this paper attempts to fill the lacuna in the literature. Some key sources of data for the study include books, journal articles and newspaper publications about the subject matter. Efforts were made to interview some past and present student activists and leaders to validate the information captured in the literature and other historical records.

In the subsequent sections of the paper, terminologies used are clarified.This is followed by a discussion of the theoretical underpinning of student activism; the evolution of student activism; the contribution of student activism to Ghana's journey towards the attainment of high quality liberal democracy; concluding remarks; and policy recommendations.

At this juncture, some concepts ought to be clarified. First, 'Fourth Republic' simply refers to Ghana's fourth attempt at constitutional democracy that started in 1992 and is still 
taking place today. Ghana's First Republic lasted from 1960 to1966; the Second Republic lasted from 1969 to 1972; and the Third Republic spanned the period between 1979 and 1981. The second term that requires clarification is 'student activism'. According to Altbach (1992, p.1444) "student activism is inherent in the nature of the academic community" and "will continue to be a powerful force", both on campus and in society. The term refers to all activities either in support of or in opposition to regimes and their leaders pursued by students of tertiary institutions. Such activities may be formal or informal; may occur both at the national level (oriented towards society) and local level (orientated towards academia, particularly in opposition to university management) (Luescher, 2005; Altbach, 1966).

Finally, 'High Quality Democracy' is the fusion of procedural (rule of law, participation, competition and accountability) and substantive (freedom, equality and responsiveness) democracy in a manner that ensures that the two interact and reinforce one another (Diamond \& Morlino, 2005). High Quality Democracies are distinguished from Low Quality ones by the fact that the latter are merely electoral democracies, that conduct relatively free and fair elections without viable and credible opposition, and the institutionalisation of the basic tenets of democracy. Such democracies according to Diamond (1997, p. 18), provide a "sufficiently fair arena of contestation to allow the ruling party to be turned out of office". However, they are hollow and a wide gap exists between them and their High Quality counterparts (Diamond, 1997). The indicators of High Quality Democracy as can be deduced include: human rights protection; equality before the law; rule of law; accountability; responsiveness; competition; and participation.

\section{Student activism in theoretical perspective}

An interesting question that has dominated the literature on student activism is the following: "What is it that makes students engage in political activity?" Related to this question is another question: "What accounts for students' radical, violent behavior?" Rubinson and Meyer (1972, p. 21) have concluded that student activism, even that of a violent nature, is determined by the extent to which the status of students is institutionalised within the national political and social systems. They argued that students as a social group achieve their political relevance by the extent to which "the authority of the educational system itself is institutionalised and regulated at the national level [...] so that educational institutions are not simply a market mechanism producing personnel for a variety of needs, but come to control as institutionalised status order whose rules help to symbolically define the personnel of the political society" (Rubinson \& Meyer, 1972, p. 24). This status definition, they argue, provides students with both the moral and normative grounds to engage in political activism. As they explained, "because in most countries, the nation-building process and its difficulties led to a formulation of the student status as socially and politically central, students generally are more politically active than other groups" (Rubinson \& Meyer, 1972). Consequently, "the variations across countries in the amount and nature of student activism result from differences in the incorporation of the status of the student". 
It is thus impossible to consider student activism without reference to the educational system within which students develop that affects their self-conception and understanding of their role within the polity (Agyeman, 1988). Historically in Ghana, education was not only seen as key to improving one's mobility prospects; it was also seen as an indispensable tool for achieving parity with the former European colonial elite and represented a symbol of pride in the Ghanaian society (Finlay, 1971). It was fairly common, until recently, to find whole communities pool their resources together in order to send "one of their own" to school (Nunyonameh, 2012, p. 5). Brammer's (1967, p. 254) observation of student status in other developing countries is an apposite description of the Ghanaian situation. "The student has a high social status and is generally revered by his elders because of the power of his knowledge and skill. He is often viewed as a champion of the people against the forces of exploitation and tyranny (p. 258). It is these implied responsibilities that naturally predispose students to political activity, as failure to 'deliver' on them is disapproved by society (Nunyonameh, 2012, p. 6).

Altbach $(1969 ; 1991 ; 1997 ; 2006)$ adds a socio-political dimension to the explanation of student activism and political behavior. According to him, the inherent characteristic features of educational systems, the transient nature of studentship, the macro-political level, the stage of political development, and responsiveness of the political system to political demands matter in shaping and influencing student activism. He further explains that students in developing countries earn a greater legitimacy for their political actions because in many such countries, the political system tends to be poorly institutionalised, and the public sphere characterised by poorly established civil society. Because such societies also have high levels of illiteracy, students are among the few groups in the society with both the knowledge and freedom to undertake political activity. Consequently, the rest of the society tends to see students as the 'conscience of the nation'. This explanation implies that any qualitative improvement in the degree of institutionalisation of the political system in these countries is certain to diminish the prominence of students in the political sphere. While this assertion may be valid in Ghana, it must be subjected to further analysis in order to establish other variables that are likely to undermine student activism. According to Luescher-Mamashela (2013), Altbach's framework involves a complex multi-level system of categorical classification as well as specific propositions regarding the emergence, outcomes and impact of student activism, response to student activism, and the characteristic features of student activists, organisations and movements.

\section{Evolution of student activism in Ghana}

\section{The years of passive activism}

In tracing the evolution of student activism in Ghanaian politics, one cannot ignore developments in the then University College of Gold Coast (UCGC) in Legon, now University of Ghana, Legon, which was established in 1948. This is not just because it 
is closer to the seat of government, but also because it is the oldest university in Ghana (Chazan, 1978, p. 8). According to Finlay, Kopplin and Ballard (1968), before the 1960s there was no tradition of student activism in student life at the UCGC. Students were somewhat aloof from national politics (Ibid.) This situation was not limited to UCGC. Indeed, according to Nunyonameh (2012, p. 6), there is little or no record of student activism prior to the 1960s in the Kumasi College of Technology (KCT), now Kwame Nkrumah University of Science and Technology, which was established four years after the UCGC.

Several explanations are proffered in discussing the initial years of inertia and lack of student activism and disinterest in national politics. First, the elitist educational system around the time tended to decrease the salience of student activism and national political activity for the individual student. According to Emerson (1968, p. 42), the educational system guaranteed the occupational aspirations of students and insulated them physically and intellectually from national politics and student activism. The high demand for skilled labour during the post-independence period and the high social status attached to university education made the acquisition of university degree a major priority for students (Agyemang, 1988, p. 69). As aptly noted by Peil (1969), students sought to rather maximise the disadvantages in their struggle for a university degree than confront the government, which incidentally was the main employer.

Secondly, the repressive political environment under the post-colonial Nkrumah regime, which made student activism a dangerous activity, could partly explain the years of inertia in student activism. Ghana's first head of state, Kwame Nkrumah, turned Ghana into a police state and under his notorious Preventive Detention Act (1958), he could detain suspected political enemies for up to five years without trial. As Goody (1968, p. 339) observed, "there was simply no community of dissent, as` the network of paid informers, the preventive arrests, above all the desire for a peaceful life, meant that open discussion of disapproval took place only between foreigners or between very close friends, if at all". The right to criticise and freedom of young people and students to rebel were effectively silenced by the authoritarian regime of Nkrumah (Goody, p. 345).

Thirdly, the traditional value of respect and deference to authority also accounted for the weak student activism around the period under review (Ofosu-Appiah, 1967). Youth and student obedience and deference to authority were certainly much more relevant before and around the 1960s than is currently the case.According to Chazan (1978, p. 10), generally, obedience to political leaders among Ghanaian youth around the time was extremely high. This contributed to the weak student activism at the time. Finally, the lack of political experience and the consequent lack of clarity of political opinion or position on critical political issues in Ghana worked against student activism (Nunyonameh, 2012, p. 4). For most students at that time, there were only two national issues: colonialism and the CPP government. While they would have decisively rejected colonialism, and while they were very dissatisfied with the Nkrumah regime, lack of clarity about the future meant that students would be more reactive than proactive to wider political developments (Nunyonameh, p. 8). 


\section{The early years of activism}

The period after 1960 marked the early years of student activism in national politics and the characteristic feature of the relationship between students and governments around the time was confrontation. Student confrontation with government arose principally between the university students in Legon and the government out of competing demands of nationalism and academic freedom (Emerson, 1968). The government clashed with students over the proper definition of the latter's role in national development. The university which was largely controlled by expatriates was unwilling to submit to partisan control because its authorities viewed it as independent of national partisan control and politics. On the contrary, the CPP government saw the university as a part of the broad nationalist machinery available for the fight against vestiges of colonialism and for national development (Ofosu-Appiah, 1967). The government interpreted the university's unpreparedness to submit to state control to mean that the university was committed to serving colonialist and imperialist rather than Ghanaians interests. Consequently, it undertook several measures including less constructive media criticisms, with the view to building popular discontent against the university (Nunyonameh, 2012, p. 9).

Further, a number of steps that invariably infuriated both students and university administrators were undertaken, including an attempt to control the university and limit academic freedom through the passage of the Universities Act (1961) that made the head of state chancellor of the universities. This helped the government to exercise some control over the universities. Even though this act incensed the students, they did not revolt until an attempt was made by the government through the 1964 Amendment Act to bring the judicial arm of government under the control of the CPP-led government (Austin, 1964). Students of the University of Ghana issued a statement condemning the move by the president to interfere in the judiciary (Austin, 1964). Again, the government's decision to purge the universities of 'subversive elements', which led to the deportation of six expatriate faculty members of the University of Ghana, drew massive student protests (Austin, 1964). By asserting themselves and criticising the CPP regime at a time when it was considered dangerous to stand in the way of the president, student activism gained some credibility and students generally succeeded in establishing themselves as a force in Ghanaian politics (Shillington, 1992, p. 45). Realising the implications of the fledgling student activism on the legitimacy of the regime, the CPP-government sought to cripple them. Indeed, shortly after the 1964 one-party state referendum which the CPP won, five Legon student leaders and a faculty member perceived to have been backing student activism were arrested and detained (Shillington, 1992).

While student activism was emerging as a major political force, the Nkrumah regime was overthrown in 1966 by the National Liberation Council (NLC). Given the harsh treatment meted out to them by the CPP regime, students of the universities hailed the coup and were quite supportive of the military regime (Chazan, 1978). Even when the NLC issued a decree against rumour mongering, the students were initially hesitant to criticise the regime. It took several weeks before the National Union of Ghana Students (NUGS) in Legon drew the regime's attention to the threat posed by the decree to the right to free 
speech (Chazan, 1978). Many students did not see the urgency in returning to civilian rule. They believed that the military regime needed time to master political administration in order to be more effective in solving pressing national problems. Therefore, the military nature of the regime did not appear to be a problem for students. Once it was not perceived to be oppressive, students did not appear overly worried (Nunyonameh, 2012, p. 11). What mattered most in the view of Emerson (1968, p. 97) was that the military coup of 1966, at the very least, marked a total symbolic break with the period of inertia in student activism and the idea of student participation in shaping national decision-making was ingrained in the psyche of many students from the tertiary institutions.

\section{Student activism in the Busia Regime: 1969-1972}

It must be noted that the fact that students were not very critical of the NLC regime, did not mean all was well with Ghana. Before Busia was elected prime minister, the country was plagued with a serious economic crisis including shortage of foreign currency, huge domestic and foreign debt, runaway inflation and high rate of unemployment. The political transition from the NLC regime to the Busia-led Progress Party (PP) was hailed by students as a solution to the economic crisis (Goldsworthy, 1973). Unfortunately, the economic hardships continued under Busia. Prices of basic goods kept soaring while the government imposed fees for medical treatment; reintroduced the payment of school fees (which had been abolished by the Nkrumah regime); and replaced the government bursary to students with a student loan scheme - a move that was sharply criticised by the students (Goldsworthy, 1973, p. 15). There were widespread student protests under Busia in a manner that compelled him to openly acknowledge in his 1969 First National Students' Day address that indeed, there was much for students to revolt about (Nunyonameh, 2012, p. 16). Despite this open confession, the government resorted to desperate authoritarian measures in dealing with student activism. Following a cabinet reshuffle in 1971, Busia took personal charge over the ministry of information and strived to guard against negative media commentaries in a manner that undermined freedom of expression. Indeed, later that year, a law to permit the government to arrest anybody who insulted Busia was being seriously considered (Nunyonameh., p.18).

Sensing a similarity between the political environment under the Busia and that of Nkrumah, the NUGS issued a communiqué in 1971 demanding freedom of speech and of the press and immediate action to deal with the worsening economic crisis of the country. In response, the government resorted to verbal attacks, accused students of treason and also referred to them as "the little minds at the universities" (Goldsworthy, 1973, p. 20). These attacks accentuated students' anger against the government and as the economic situation worsened and attempts to silence the students heightened, student protest became more vociferous and attracted the support of Ghana's Trades Union Congress (TUC) (Goldsworthy). The two groups teamed up to against the government and formed a much dreaded alliance when in September 1971, the government further sought to dissolve the TUC by introducing the Industrial Relations Amendment Act (Ninsin, 1985a). It was their protests that ultimately laid the foundation for the military takeover by Acheampong in January 1972 (Ninsin, 1985a). 


\section{Student activism under the Acheampong regime}

The Acheampong-led National Redemption Council (NRC), which later became the Supreme Military Council (SMC), attempted to shore up its legitimacy by resorting to several public relations gimmicks. According to Chazan and LeVine (1979), the regime fully appreciated the influential role of students and sought to win their support by abolishing the student loan scheme and replacing it with government bursaries; increasing the salaries of workers; and revaluing the nation's currency. The regime introduced some initiatives which were supported by students. These include the national food self-sufficiency programme called 'Operation Feed Your Self' (OFYS) which enjoined all Ghanaians to venture into agriculture, particularly food production; the repudiation of all foreign debts popularly called the 'yentua policy'; and the construction of irrigation projects. Students responded positively to the food-sufficiency initiative by abandoning their studies to assist in the harvesting and transportation of sugarcane from Komenda in the Central Region, for further processing. They also assisted in the construction of several irrigation projects in Dawhenya, Afife, Tano, etc. and applauded the 'yentua policy' (Oquaye, 1980). As a sign of patriotism, the students recommended the establishment of a National Service Scheme that would mandate graduates from tertiary institutions who had benefitted from free education to render one one year voluntary service to the nation. This suggestion was accepted and it led to the passage of the National Service Decree (208) in 1978 (Shillington, 1992).

However, the 'yentua policy' had alienated the regime from the donor community and as OFYS could not be sustained, this among others, led to mounting economic hardships with no assistance from the country's debtors. Consequently calls for a return to civilian rule were made and the pressure was led by the students (Hitchens, 1979, p. 171). The government responded to the calls in October 1976 by proposing a 'Union Government'a concept that provides space for traditional authorities, military and police to co-rule the country almost permanently (Oquaye, 1980). As Chazan and Le Vine (1979, p. 178) noted, "the government had made it abundantly clear that a return to civilian rule did not mean government without military participation”. But the students viewed this proposal as an attempt by the soldiers to perpetuate themselves in power and therefore resorted to massive protests and violent demonstrations (Owusu, 1979). Nevertheless, the regime went ahead to subject the 'Unigov' idea to a referendum in March 1978 and claimed to have won the outcome. The referendum was marred by violent and extra-legal as well as confrontational forms of opposition, led by the students. This resulted in several clashes between students and the police in a manner that forced the closure of the universities for several days (Chazan \& Levine, 1979, p.188).

It was this state of 'praetorianism' coupled with the serious economic hardships and corruption that led to a palace coup by General F.W.K. Akuffo to kick out Acheampong and to establish the Supreme Military Council (II) (Shillington, 1992). Perceiving political parties as ethnic and divisive entities, the Akuffo regime also proposed a 'National Government' under which it would rule for a transitional period of at least four years. But the students became suspicious of this intention and uncompromisingly opposed it 
(Ninsin, 1985a). Perhaps terrified by the sustained student agitation, the regime abandoned the 'National Government' proposal in favour of multiparty politics (Ninsin, 1985a). It announced a timetable to return the country to civilian rule in July 1979. However, as preparations towards the 1979 elections slated for June were underway, Flt-Lt J.J. Rawlings led a group of junior army officers to topple the Akuffo regime in June 4, 1979 and established the Armed Forces Revolutionary Council (AFRC) (Ninsin, 1985a).

\section{Students' first encounter with Jerry Rawlings}

The AFRC engaged in a 'house-cleaning exercise' aimed at purging the nation of corruption and announced a return to civilian rule in September 1979. The support offered the AFRC by students through the issuance of statements and demonstrations was unflinching and unprecedented (Nunyonameh, 2012, p. 18). The regime sought to garner student ownership of its activities by appointing a representative on student affairs who collated student input into its programmes. Students supported the regime's bloody housecleaning exercise by chanting in support of the execution, public flogging and ridiculing of those tagged by the regime as corrupt economic saboteurs (Shillington, 1992, p. 51). They also abandoned their studies and went to the hinterlands to help transport locked-up cocoa and foodstuffs to the city centres (Shillington, 1992).

The initial support of the regime notwithstanding, its brutalities and egregious human rights abuses began to cause some public disaffection. The Ghana Bar Association (GBA) and TUC openly criticised the regime for its ruthlessness. However, students described these criticisms as unwarranted and embarked on street protests to demonstrate their continuing support for the regime (Nunyonameh, 2012, p. 19). To the students, the AFRC was the solution to the problem of political power and social justice. They were bitter against the Acheampong-led SMC because of the violence the regime unleashed against them and hence were prepared to defend the AFRC that ousted the SMC to the hilt. This also explains why they supported Jerry Rawlings again, when on December 31, 1981, he overthrew the civilian government he had handed over power to in 1979 and established the Provisional National Defence Council (PNDC) (Shillington, 1992).

\section{Students' second encounter with Jerry Rawlings}

The support accorded the PNDC during the students' second encounter with Jerry Rawlings was momentary. The students, typically, demonstrated what is much known about them when they felt the fiduciary trust bestowed on the PNDC was betrayed. Even though the regime was provisional and was expected to return the country to a multiparty democracy, it lacked the political will to do so. Hence by 1983, students had joined other civil society groups to agitate for the handing over of power to a more democratic government (Shillington, 1992). The previous regime that Rawlings overthrew, led by Dr Limann, passed the National Service Act 426 (1980) that increased the number of years for students to do national service from one to two years, six months of which was to be spent on military training. However, students objected to this law which was about 
to be implemented by the PNDC regime in the period around the end of 1983. Again, the 1983 budget contained austerity measures prescribed by the World Bank including cost-sharing in education at both secondary and tertiary level. In response to this, students under the aegis of the NUGS embarked on a nationwide demonstration, boycotted lectures and resorted to other acts of violence because, according to Haruna Iddrissu, a former NUGS president (personal interview, May 7,2013) they felt education was a 'right' and not a 'privilege'. The regime sought to undermine and weaken the student front by resorting to threats and intimidation including the disruption of the annual congress of the NUGS in May 1983 that resulted in the destruction of property and injuries to both students and cadres of the regime. This led to the arrest of some of the student leaders, including Kweku Paintsil, the then NUGS president. According to Gyimah-Boadi (1993), the PNDC, realising the threats posed to its security by students, did not hesitate to repress them. Unfortunately, the students could not secure the support of the public as they were subjected to harsh brutalities, ostensibly as a way of letting them taste the poison they assisted the regime in preparing through their open support for the AFRC/PNDC even when the rights of other Ghanaians were being violated (Nunyonameh, 2012, p. 9).

\section{Student activism and Ghana's transition to the Fourth Republic}

After holding on to the reins of power in its 'provisional status' for a period of 11 years, the PNDC regime eventually had to succumb to pressures to return Ghana to constitutional rule. These pressures were both internal, from students and other civil society groups, as well as external, through the application of political conditionalities for loans from the World Bank (Shillington, 1992). In calling for a return to constitutional democracy, the students argued that a democratically elected government would accommodate all shades of opinions and would not implement unpopular policies like the austerity measures introduced under the aegis of the Structural Adjustment Programme (SAP). According to Ninsin (1996b), the PNDC was adamant about retaining its 'indispensable' hold over power and did not feel enthused to negotiate the transitional process with students and other civil society groups that had called for a return to constitutional rule. However, the groundswell of pressure for a return to multiparty democracy compelled the regime to put in place preparatory measures to usher the country into a constitutional dispensation (Ninsin, 1996b).

The preparatory processes were less consultative and in September 1990, students held a press conference to call on the regime to desist from controlling the process and open the political space for all groups to operate. According to K. Paintsil (personal communication, May 6, 2013) the students among others called for the repeal of all oppressive laws and decrees, and the unconditional release of political prisoners. However, these demands were ignored by the regime and in protest, the students also boycotted the activities of the Consultative Assembly that was tasked to draft the 1992 Constitution because its composition too, was packed with supporters of the regime (Gyimah-Boadi, 1993). As the draft Constitution became ready for a referendum, the students issued a statement to condemn the PNDC for the less inclusive manner in which document was drafted. 
They also criticised the Consultative Assembly for allowing the regime to smuggle such "transitional provisions as would allow the PNDC and her cohort of appointees to go unquestioned about their performance" (Ninsin, 1996b, p. 141). Again, these criticisms were ignored by the regime as it went ahead to subject the draft Constitution to a referendum in April 1992 and secured approval for it; lifted the ban on political parties in May 1992; mutated into the NDC under the leadership of Jerry Rawlings; contested and won the November/December 1992 general election in which Rawlings was described as 'the referee, footballer and linesman' (Ibid.). Rawlings ruled for eight years and handed over power to J.A. Kufuor of the NPP after the NDC had been defeated in the 2000 general elections. Kufuor also ruled for eight years and handed over power J.E.A. Mills after the NPP had lost the 2008 general elections. J.E.A. Mills ruled for three years, seven months and departed to eternity. However, his party, the NDC under the flag-bearership of John Mahama, won the 2012 General Elections.

\section{Student contribution to democratic quality in the Fourth Republic}

Since the inception of the Fourth Republic in 1992, the militant posturing of students seems to have subsided and the NUGS is not much heard commenting on national issues and criticising governments. Indeed, some former NUGS presidents like S.O. Ablakwah (personal interview, July 3, 2013) have even described the Ghanaian student movement as being in a state of coma. However, one thing that is being lost by those who are used to the militant posturing of students is that the Fourth Republic is the only period of democratic governance in the political history of Ghana that has been allowed to thrive for more than 20 years. Students, particularly during the SMC and PNDC rule, agitated for a constitutional democracy where there would be no dictatorships, and where freedoms and human rights and vibrant activism of other civil society would be institutionalised. The Fourth Republican dispensation seems to have guaranteed these democratic ideals, albeit at a low level. Again, knowing the role they played in making regimes unpopular, politicians under the Fourth Republic seem to have been proactive in infiltrating the camp of students, particularly the NUGS. Whoever emerges the NUGS president is of utmost concern to political leaders. Hence they have tried their best to corrupt and influence the election of student leaders to ensure that such leaders do not become overly critical of government. Such leaders have also encouraged the emergence of splinter groups and massive secessions from the NUGS (Gyampo, 2012b). These have contributed to weakening the leverage of the NUGS as the mouthpiece of students and dented its legitimacy (Gyampo, 2012b).

Notwithstanding attempts to influence and break their front by politicians and their generally less confrontational posturing in the Fourth Republic, students activism has somehow contributed towards deepening the quality of democracy in Ghana. Student activism since 1992 has mainly manifested on the various university campuses through the political party/tertiary student network. According to Asante (2012, p. 12), tertiary student networks evolved as a movement in tertiary institutions following the ushering of the country into constitutional democracy in 1992. On the campuses of the traditional tertiary institutions 
like the University of Ghana (UG), University of Cape Coast (UCC) and the Kwame Nkrumah University of Science and Technology (KNUST), students were encouraged by the various political parties to organise themselves along political and ideological lines. Students who believed in the traditions of the NPP formed a movement of the party on the campuses. Those who shared the ideals of Jerry Rawlings also formed a branch of the NDC on the campuses while the adherents of Nkrumahism launched branches of the CPP (Asante, 2012, p. 13). These branches of the NDC, NPP and CPP were later renamed Tertiary Institution Network (TEIN), Tertiary Education and Students Confederacy (TESCON) and Tertiary Students' Charter (TESCHART) respectively. The idea was later extended to polytechnics, training colleges, the University of Professional Studies, and more recently, private tertiary institutions throughout the country (Ibid.). According to A.M. Ayuba, president of TEIN (personal interview, May 7, 2013), the functions of these tertiary networks are to defend and support their political parties during elections; win more members and supporters for their parties on the various campuses; and educate students about the ideologies, manifestoes and policies of the political parties. In the discharge of their functions, these networks have created a positive image of student activism by contributing to the shoring up of democratic quality in Ghana in the areas of human rights promotion and protection, political equality, accountability, responsiveness and participation. These are discussed below.

\section{Human rights}

In the area of human rights and freedoms, it is instructive that, since 2002, Ghana has been consistently rated high as a free country by Freedom House. Indeed, in their assessment of the quality of democracy in Ghana and South Africa, Mattes and Gyimah-Boadi (2005, p. 261) scored Ghana 2 for both political and civil liberties on a scale of 1:7 in 1996, and rated the country free in terms of press freedom. Yet, there are many challenges regarding human rights protection in Ghana. There appears to be growing intolerance and indiscipline, mob lynching of suspected armed robbers and the prevalence of vigilante justice, particularly in the urban and peri-urban centres of Ghana (Asante, 2012, p. 20). In this atmosphere, tertiary networks have been canvassing for tolerance of opposing views and the need to respect the rights of all. Indeed in 2011, both the University of Ghana branch of TEIN and TESCON issued statements to condemn the inhuman treatment meted out to a female suspect alleged to have stolen mobile phones belonging to some students of Akuafo Hall of the University of Ghana (Asante, 2012).

There are even more serious deficits in socio-economic rights. The directive principles of state policy of Ghana's 1992 Constitution that assures all Ghanaians of their right to employment for example, is not justiciable and governments cannot be prosecuted for joblessness. Hence unemployment rates keep rising and efforts to deal with the situation by governments can be described as drops in the ocean. According to the 2012 Report of the Institute of Statistical, Social and Economic Research (ISSER) of the University of Ghana, 250000 people enter the labour market annually, of which the public sector is able to absorb only $2 \%$. ISSER further estimated that youth unemployment (in relation 
to the active and legal employable population of $18-60$ years) has risen from $14.8 \%$ in 1992 to $16.4 \%$ in 2000 and came close to $36 \%$ in 2012. This partly explains the formation of the Unemployed Graduates Association in 2011 by students who had completed their education at the tertiary level. Tertiary networks across the country have viewed the unemployment problem as a major human rights issue and made several calls on government to treat the issue as a national priority. Apart from the security reasons cited by the then national security coordinator, Sam Amoo as the main reason for the introduction of the National Youth Employment Programme (NYEP) in 2006, there is evidence to show that some of the calls and advocacy by student activists operating through the tertiary networks across the country also influenced the setting up of the NYEP (Gyampo, 2012b, p. 19). Even though the NYEP is described as an ad hoc and 'quick fix' solution with several challenges, it has assisted in lessening the burden of unemployment in Ghana by providing employment to over 100000 young people by the close of 2012 (Gyampo, 2012b).

\section{Equality}

Ghana's 1992 Constitution guarantees political equality. However what pertains in practice is different. The 2002 Afrobarometer survey conducted by the Ghana Center for Democratic Development (CDD-Ghana) revealed the heightened perception of inequality under the law. According to the survey, $28 \%$ of respondents complained about political inequality. Beyond political inequality, there is widespread gender as well as socio-economic inequality in the country with women participation in decision-making being relegated to the background; and income inequality among many Ghanaians (Asante, 2012, p. 22). Student activists operating through tertiary networks of political parties have played a crucial role as important advocates for political, socio-economic and gender equality. They have however been 'loud' in the area of political equality. They have constantly advocated for their inclusion in the selection of party officials and candidates including flag bearers of national election. As a result of this advocacy, the NDC for instance has a representative of the youth and student activists at all levels of the party, from the branch to the national level. According to L. Hlordze, national youth organiser of the NDC (personal communication, May 7, 2013), these young representatives now have voting rights in the selection of party executives and flag bearers. TESCON and TESCHART have also gained greater voting rights and recognition in party administration, decision-making and selection of party officials at congresses (Asante, 2012, p. 24). In addition, these student activists are now allowed to contest for elective positions in their respective parties. Indeed, according to E.A. Kissi, an Electoral Officer at the Electoral Commission of Ghana (personal communication, May 3, 2013), this explains why the number of student activists who contested for parliamentary primaries increased from $48 \%$ in 2008 to $66 \%$ in 2012.

\section{Accountability}

Student activism has also contributed to promoting both vertical and horizontal accountability. In terms of vertical accountability, students are part of the majority of 
the voting population who have either rewarded incumbent leaders or punished them by voting them out of power (Diamond \& Morlino, 2005). It is instructive that the dynamics of vertical accountability go beyond the interplay between voters and their elected representatives. It also encompasses the efforts of civil society, mass media and social movements to hold governments accountable in inter-election periods (Diamond and Morlino, 2005). In Ghana however, the media's ability to promote accountability is limited by huge gaps in levels of professionalism and integrity (Asante, 2012, p. 17). Again, many civil society groups have failed to demonstrate high levels of internal accountability while others have weak capacity. As key political actors, students at the tertiary institutions vote massively during elections and passionately demand accountability from government and party officials. On various platforms, they express concern about how leaders handle national issues including cost of living, energy crisis and general state of the economy. On March 10, 2012, for instance, the University of Ghana branch of TESCON issued a statement calling on government to find an immediate and lasting solution to the nation's power crisis. This subsequently compelled the government to announce measures being put in place and the dates on which the crisis would end.

In terms of horizontal accountability, tertiary networks have been supportive of both legal and voluntary agencies committed to promoting accountability. They have collaborated with groups committed to observing and monitoring elections in Ghana like the Coalition of Domestic Observers (CODEO), the Institute of Economic Affairs (IEA-Ghana), CDD-Ghana and the Christian Council of Ghana. Again, at the national level, they have advocated for accountability, fairness and transparency in electoral management. Indeed, both TEIN and TESCON have been actively involved in the monitoring of elections (Asante, 2012, p. 18). Student activists on the various campuses, particularly TEIN and TESCON members, serve as polling agents and registration officers in the rural hinterlands and in the strongholds of other parties. For example, in the 2000 elections, some members of TESCON demonstrated bravery and risked their lives for the NPP when they served as polling agents in the Volta Region, an NDC stronghold and a 'no go area' for the NPP. According to A.M.Ayuba and B.K.A.Asena, presidents of TEIN and TESCON respectively (personal interviews, May 7, 2013), TEIN members were also deployed to the Ashanti Region (which is also the "World Bank of the NPP") as polling agents for the NDC in the 2008 general elections. Some of the students were assaulted by their political opponents because of their vigilance in preventing rigging and other electoral irregularities (Asante, 2012, p. 21). Furthermore, tertiary networks have constantly opposed undemocratic ways of running political parties and have called for genuine accountability in the running of political parties including the nomination and selection of candidates for elections to all positions and party financial statements (Asante, 2012, p. 22).

\section{Responsiveness}

The degree to which governments put in place policies to deal with the priorities and needs of the ordinary people show how responsive they are (Diamond \& Morlino, 2005). In 
the CDD-Ghana 2002 Afrobarometer survey, the majority of Ghanaians (51\%) emphasised the need for governments to deal with unemployment as their top priority. However, the survey showed that only $22 \%$ believed governments are responsive to the needs of the people. This implies that there is a general deficit in terms of governmental responsiveness in Ghana. However, student activists operating through tertiary networks across the country have contributed to making governments somewhat responsive through their calls and insistence on more public involvement in the formulation and implementation of policies. In formulating Ghana's mid-term development plan - the Ghana Shared Growth and Development Agenda, 2010-2013 in 2009 - tertiary networks on the various campuses called for broader consultations and participation in the planning processes to ensure that the development plan reflects the needs of the people (Gyampo, 2012c, p. 138). In 2006, the Accra Polytechnic branch of TEIN held a seminar on 'The Impact of Democracy on Nation Building'. Similarly, the University of Ghana branch of TESCHART organised a forum on March 6, 2007 on the topic 'Fifty Years of Economic Opportunities, the Lessons and the Drawbacks, What are the alternative Policies and Programmes needed for Ghana?' The University of Ghana branch of TEIN also organised a forum in 2007 on 'The Role of Undergraduate Students in Ghana's Democracy'. In 2008, the University of Professional Studies branch of TESCON also organised a series of symposia on the National Youth Employment Programme. Moreover in 2007, all the tertiary networks in the country joined forces to demand the abolition of a new residential policy that gave accommodation only to first year students. All these moves were aimed at making leaders responsive to the priorities and needs of the ordinary people (Asante, 2012, p. 18).

\section{Participation}

Participation, a key attribute of high democratic quality, can be explained in terms of the deliberate involvement of people in a decision-making process in a manner that makes them capable of influencing and owning the process (Gyampo, 2012c; Verba, Schlozman \& Brady, 1995). In Ghana, participation generally tends to be pseudo, as genuine participation in political party activities is weak and confined narrowly to only voting (Gyampo, 2012c). By virtue of their level of education, tertiary networks possess the skills needed to effect genuine participation. In this regard, it is instructive that student activists operating through the tertiary networks tend to work with other civil society groups to peacefully protest against policies believed not to be in the interest of the ordinary people. Indeed, between 2005 and 2007, members of TEIN and TESCHART were instrumental in the series of peaceful protests organised by the Committee for Joint Action (CJA), a pressure group, against some government policies such as increases in utilities, petroleum prices and the Representation of Peoples Amendment Bill (Asante, 2012, p. 23). Students of the various campuses have also been utilising their research skills, talents and knowledge to foster innovative research to support the activities of their parties. Most of the research work for the election petition filed by the NPP to challenge the declaration of John Mahama as the elected president in Ghana's 2012 general elections was done by TESCON members 
drawn from the various tertiary institutions across the country. Generally, TEIN and TESCON have vibrant research committees which plan and undertake regular research activities for their parties, particularly during elections. This form of student participation and activism helps the parties to develop appropriate campaign strategies and to predict the outcome of elections with some degree of certainty (Asante, 2012, p. 26).

\section{Conclusion and recommendation}

Clearly, the nature of student activism in Ghana has been as a result of the normative and moral grounds to engage in political activity as well as the status conferred on them by the educational system in line with the views of Rubinson and Meyer (1972). Again, that student activism generally appears to have subsided is partially due to the relative growth in Ghana's democracy and the fact that other independent civil society groups have emerged in Ghana to dilute the hitherto role of students as "the conscience of the nation" as argued by Altbach $(1969 ; 1991 ; 1997 ; 2006)$. The point must however be made that even though student activism in the nation's Fourth Republic has almost been doused, it has made a contribution to Ghana's journey towards high quality liberal democratic status. Given that Ghanaians seem to have fully accepted democracy as the preferred form of government and democratic relapse seems impossible, it can be argued that the nation is not likely to witness the confrontational student activism that existed before 1992.

Nevertheless other challenges that undermine student activism must be dealt with. In this regard, political leaders who are committed to increasing the quality of Ghana's democracy must assist in resuscitating the NUGS from its current state of coma by refraining from intruding and interfering in the activities of NUGS. Of course the leadership of the NUGS must also reassert itself and strive to exist independent of the control of politicians as they used to be in time past. This would help rebuild their credibility in the eyes of political leaders. The various student networks are limited in the extent to which they can go in their contribution to democratic quality due to their sometimes partisan posturing and outlook. Given that the various vice chancellors, Rectors and Principals of these tertiary institutions have expressed grave concern about partisan activities by students on the campuses and have threatened to ban such networks, a renewed and credible mouthpiece of students that is more national in outlook instead of campus-based may be appropriate to champion the cause of students and contribute effectively towards Ghana's democratic quality. In this regard, a revival of the NUGS of the days Nkrumah, Acheampong and Rawlings regimes that was independent in its thoughts and actions, and an amalgamation of all tertiary networks and other student splinter groups under the NUGS, is recommended. The NUGS could serve as a forum for political dialogue and tolerance among the leadership of all partisan and splinter youth groups. In other words, the revived NUGS may not be necessarily confrontational as it was in time past but may resort to dialogue, peaceful protests and petitions to achieve its objectives. These recommendations would ensure that student activism continues to serve as one of the major fulcrums around which Ghana's continuous quest for democratic quality and maturity would revolve. 


\section{References}

Agyemang, D.K. (1988). Ideological education and nationalism in Ghana under Nkrumah and Busia. Accra: Ghana Universities Press.

Altbach, P.G. (1966). Students and politics. Comparative Education Review, 8(2): 137.

Altbach, P.G. (1969). Student power: Politics and revolution: Change. Retrieved July 10, 2013, from http:// findarticles.com/p/articles/mi_m1254/ai_56250797/pg_2

Altbach, P.G. (1991). Student political activism. In: International Higher Education: An Encyclopedia. New York \& London: Garland.

Altbach, P.G. (1992). Politics of students and faculty in B.R. Clark \& G. Neave (Eds.) The Encyclopedia of Higher Education. New York: Pergamon.

Altbach, P.G. (1997). Student politics in America: A historical analysis. London: Transaction.

Altbach, P.G. (2006). Student politics: Activism and culture in J.J.F. Forest \& P.G. Altbach (Eds.) International Handbook of Higher Education. Dordrecht: Springer.

Asante, R. (2012). The youth and future of democracy in Ghana. Accra: Ghana Universities Press.

Austin, D. (1964). Politics in Ghana: 1946-1960. London: Oxford University Press.

Awoonor, K.N. (1990). Ghana: A political history from pre-European to modern times. Accra: Sedco.

Brammer, M.L. (1967). The student rebel in the university: A world-wide view. The Journal of Higher Education, 38(5), 257-262.

Emerson, D.K. (1968). Students and politics in developing nations. London: Pall Mall Press.

Chazan, N. (1978). Political culture and socialization in politics: A Ghanaian case. The Review of Politics, 40 (1), 2-31.

Chazan, N. (1983) An anatomy of Ghanaian politics: Managing political recession. Boulder CO: Westview, pp. 141-160.

Chazan, N., \& Le Vine, V.T. (1979). Politics in a Non-Political System: The March 301978 referendum in Ghana. African Studies Review, 22 (1), 176-207.

Diamond, L. (1997). Is the third wave of democratization over?: An empirical assessment. Retrieved April 20, 2013 from http://nd.edu/-kellogg/publications/workingpapers/WPS/236.pdf .

Diamond, L., \& Morlino, L. (2005). Assessing the quality of democracy. Baltimore: The Johns Hopkins University Press.

Finlay, D.J. (1971). Education and polity in Ghana. History of Education Quarterly, 11(3), 319-327.

Finlay, D.J., Kopplin, R.E. \& Ballard, C.E. Jnr. (1968). Ghana in D.K. Emerson (Ed.) Students and Politics in Developing Nations. London: Pall Mall.

Goldsworthy, D. (1973). Ghana's second republic: A post-mortem. African Affairs, 72(286), 8-25.

Goody, J. (1968). Consensus and dissent in Ghana. Political Science Quarterly, 83 (3), 337-352.

Gyampo R.E.V. (2012a). The youth and political ideology in Ghanaian politics: The case of the fourth republic. African Development. XXXVII (2), 135-163.

Gyampo, R.E.V. (2012b). Youth participation in youth programmes: The case of Ghana's national youth employment programme. The Journal of Pan African Studies, 5(5), 13-28.

Gyampo, R.E.V. (2012c). The youth and development planning in West Africa: The case of Ghana's fourth republic. African Journal of Social Sciences, 2(4), 130-146. 
Gyimah-Boadi, E. (1993). The search for economic development and democracy in Ghana: From Limann to Rawlings. In E. Gyimah-Boadi (Ed.) Ghana under PNDC rule. Accra: CODESRIA.

Herbst, J. (1993). The politics of reform in Ghana, 1982-1991. Berkeley: University of California Press.

Hitchens, D.R.M. (1979). Towards political stability in Ghana: A rejoinder in the union government debate. African Studies Review, 22(1), 170-176.

Kaufmann, D., Aart, K., \& Massimo, M. (2004). Governance Matters 111: Governance indicators for 19962002. Washington DC: World Bank.

Kimble, D. (1963). Political history of Ghana: The rise of Gold Coast nationalism, 1850-1928. Oxford: Oxford University Press.

Lentz, C. (1995). Unity for development: Youth associations in North-Western Ghana. Journal of the International African Institute, 65 (3), 395-342.

Luescher, T.M. (2005). Student governance in Africa: Thematic summary of key literature. Retrieved August 12, 2013 from http://ahero.uwc.ac.za/index. php?module $=$ cshe\&action $=$ downloadfile\&fileid +81806115511936453717868 .

Luescher-Mamashela, T. (2013). Theorizing student activism in and beyond the twentieth century: The contribution of Philip G. Altbach. Paper presented at the Students in twentieth century Europe Symposium, University of Portsmouth, July 17, 2013.

Lumsden, D. (1980). Towards Ghana's third republic. Canadian Journal of African Studies, 13(3), 471-477.

Mattes \& Gyimah-Boadi (2005). Ghana and South Africa. In L. Diamond \& L. Morlino (Eds.) Assessing the Quality of Democracy. Baltimore: The Johns Hopkins University Press.

Ninsin, K. (1985). Political struggles in Ghana, 1967-1981. Accra: Tornado.

Ninsin, K. (1996). Ghana's political transition 1990-1993: Selected documents. Accra: Freedom.

Nugent, P. (1996). Big men, small boys and politics in Ghana. Accra: Asempa.

Nunyonameh, C. (2012). Politics and democracy in Ghana: Trends and issues. Accra: Ghana Universities.

Ofosu-Appiah, L.H. (1967). Authority and the individual in Ghana's educational system. The Legon Observer, (6), 4-5.

Oquaye, M. (1980). Politics in Ghana, 1972-1979. Accra: Tornado.

Owusu, M. (1979). Politics without parties: Reflections on the union government proposals in Ghana. African Studies Review, 22(1), 88-108.

Peil, M. (1969). Ghana's universities and their government: An ambiguous relationship. Issues in African Higher Education, XXIV(1), 52-56.

Peil, M. \& Odotei, E.O. (1967). Return to civilian rule. The Legon Observer. (9), 3-10.

Rubinson, R. \& Meyer, J. (1972). Structural determinants of student political activity: A comparative interpretation. Sociology of Education, 45(1), 23-46.

Shillington, K. (1992). Ghana and the Rawlings factor. London: Macmillan.

Tetteh, M.N. (1999). The young pioneer movement: A youth organization in Kwame Nkrumah era. Accra: Ghana Publicity.

Verba, S., Schlozman, K.L., \& Brady, H.E. (1995). Voice and equality: Civic voluntarism in American politics. London: Harvard University Press. 